\title{
Growth of Audouin's gull chicks: the role of prehatch and posthatch factors*
}

\author{
ELENA VILLUENDAS and BLANCA SARZO \\ Centro de Protección y Estudio del Medio Natural (C.P.E.M.N.), Avda. de los Pinares 106, 46012 El Saler, Valencia, \\ Spain. E-mail: centro.granja@cma.m400.gva.es
}

\begin{abstract}
SUMMARY: We compared the growth rates of Audouin's Gull (Larus audouinii) chicks from the Ebro Delta and Columbretes Islands. Chicks from the Columbretes Islands were reared in captivity and fed ad libitum. Wild chicks from the Ebro Delta weighed more than chicks hatched from Columbretes eggs but attained a lower weight at fledging. Chicks from Columbretes eggs hatched with a longer wing length but rates did not differ between samples during the early stages of growth. Eggs from the Ebro Delta were significantly larger than eggs from Columbretes. Hence, differences in growth appeared not to be related to differences in egg size (prehatch factor) but only in parental quality (posthatch factor) through the amount of food delivered to chicks. These differences could be due to the incapacity of parents to provide enough food during the last stages of chick development, in part because of reduced food availability at the Ebro Delta during the study period. Alternatively, differences could be attributed to a trade-off between present and future reproduction. Demographic consequences of reduced food availability for the 1993 Ebro Delta cohort should be explored in future work.
\end{abstract}

Key words: growth, Audouin's Gull, Larus audouinii, chicks, Ebro Delta, Columbretes, parental quality, egg size.

RESUMEN: CRECIMIENTO DE POllos DE GAVIOTA DE Audouin: El PAPEL DE los FACTORES PRE Y POST EClosión. - Este trabajo compara las tasas de crecimiento de pollos de Gaviota de Audouin (Larus audouinii) procedentes de huevos del delta del Ebro y de las islas Columbretes. Los pollos de las islas Columbretes fueron criados en cautividad y alimentados ad libitum. Los pollos salvajes del delta del Ebro pesaron más que los pollos procedentes de huevos de Columbretes, pero alcanzaron un peso menor en el momento de volar. Los pollos procedentes de huevos de Columbretes eclosionaron con una mayor longitud de ala pero las tasas de crecimiento no difirieron durante las primeras etapas de crecimiento. Los huevos del delta Ebro fueron significativamente más grandes que los huevos de Columbretes. Por tanto, las diferencias en el crecimiento parecieron no estar relacionadas con las diferencias en el tamaño del huevo (factor preeclosión) sino solo de la calidad parental (factor posteclosión), a través de la cantidad de comida suministrada a los pollos. Estas diferencias podrían ser debidas a la incapacidad de los padres de proporcionar suficiente comida durante las últimas fases del desarrollo de los pollos, en parte debido a una disminución en la disponibilidad de alimento en el Delta del Ebro durante el periodo de estudio. Por el contrario, las diferencias se podrían atribuir a un compromiso entre la reproducción presente y futura. Las consecuencias demográficas de la reducción en la disponibilidad de alimento para la cohorte de 1993 de Gaviota de Audouin en el delta del Ebro, deberían ser analizadas en el futuro.

Palabras clave: crecimiento, Gaviota de Audouin, pollos, Delta del Ebro, Columbretes, calidad parental, tamaño del huevo.

\section{INTRODUCTION}

Growth rates of chicks are important because growth may influence future survival and reproduction (Bolton, 1991). Chick growth can be affected

*Received October 5, 2001. Accepted September 8, 2002. both by prehatch (i.e. egg size) and posthatch (i.e. parental care) factors (Risch and Rohwer, 2000). The main prehatch factor affecting egg size is food availability (see e.g. Hébert and Barclay, 1988; Hiom et al., 1991; Bolton et al., 1992; Pons and Migot, 1995), so egg size reflects the conditions of food availability in the area surrounding colonies 
during the period of egg formation (Bolton et al., 1993). The main posthatch factor is parental quality through the amount and quality of food delivered to chicks (see e.g. Nisbet, 1978; Coulson and Porter, 1985; Bolton, 1991; Risch and Rohwer, 2000).

We performed an experiment to separate the effects of prehatch and posthatch factors on the growth rates of the chicks of Audouin's Gull Larus audouinii. Nestlings hatched from large eggs were reared under food-stress conditions by wild parents (i.e. during the 1993 trawling moratorium that coincided with the chick-rearing stage in the Ebro Delta preventing chicks to be fed with fishing discards at a usual rate) (Oro et al., 1996b). Chicks hatched from smaller eggs from the Columbretes Islands were reared during the 2000 breeding season under $a d$ libitum feeding conditions (captivity).

\section{METHODS}

Eggs were laid under periods of normal food availability (i.e. May) both at Columbretes Islands and the Ebro Delta, since the trawling-fishing moratorium was not implemented until June-July (Oro et al., 1996a; Columbretes wardens, pers. comm.). Ninety-seven eggs from Columbretes and 217 eggs from the Ebro Delta were measured with a digital caliper to the nearest $0.05 \mathrm{~mm}$ to obtain the volume. Egg volume was estimated from the equation (Hoyt, 1979),

$$
\begin{gathered}
\text { Egg volume }\left(\mathrm{cm}^{3}\right)= \\
=0.000467 \times \text { length }(\mathrm{mm}) \times \text { width }^{2}(\mathrm{~mm})
\end{gathered}
$$

Egg measurements were done by two different teams but following the same procedure (D. Oro at the Ebro Delta and EV and BS at the Columbretes Islands). Egg measurements do not necessarily correspond to the eggs from which our chick measurements were taken. However, we assume that egg measurements from the Ebro Delta and Columbretes Islands were representative of both colonies since sample sizes were large.

At the Ebro Delta nests were surrounded by a wire fence (see Oro et al., 1996a) and 106 chicks were measured (wing length and weight) every three days from hatching to fledging. Wing length was measured by means of a digital caliper to the nearest $0.05 \mathrm{~mm}$ and weight by means of several spring balances $(50 \pm 1 \mathrm{~g}, 100 \pm 5 \mathrm{~g}, 500 \pm 10 \mathrm{~g})$.

Forty-five chicks from the Columbretes Islands were taken into captivity and fed ad libitum with fish at the facilities of the Centro de Protección y Estudio del Medio Natural of the Valencian Government. Each chick was measured (wing length and weight) every three days from hatching to release. Wing length was measured with a ruler to the nearest 0.5 $\mathrm{mm}$ and weight by means of a digital balance to the nearest $0.05 \mathrm{~g}$.

Chick measurements from the Ebro Delta and Columbretes were also done by the same two teams. Only those variables measured following the same field procedures were considered in this study (i.e. weight and wing length).

Data analysis was carried out by means of an SPSS package (SPSS for Windows, Re. 10.0.6., 1999). For the analysis of the average weight gain curve, the straight (age classes 2 to 9) and the

TABLE 1. - Mean weight and wing length for captive and wild-reared Audouin's gull (Larus audouinii) chicks for each age class. Each age

\begin{tabular}{|c|c|c|c|c|c|c|c|c|}
\hline \multirow[b]{3}{*}{ Age class } & \multicolumn{4}{|c|}{ Weight (g) } & \multicolumn{4}{|c|}{ Wing length $(\mathrm{cm})$} \\
\hline & \multicolumn{2}{|c|}{ Captivity } & \multicolumn{2}{|c|}{ Wild } & \multicolumn{2}{|c|}{ Captivity } & \multicolumn{2}{|c|}{ Wild } \\
\hline & Mean & SE & Mean & $\mathrm{SE}$ & Mean & SE & Mean & SE \\
\hline 1 & 42.82 & 0.61 & 49.23 & 0.43 & 2.74 & 0.03 & 2.32 & 0.02 \\
\hline 2 & 72.61 & 1.91 & 96.32 & 2.48 & 3.63 & 0.06 & 3.22 & 0.05 \\
\hline 3 & 132.50 & 3.72 & 134.21 & 4.16 & 5.12 & 0.12 & 3.82 & 0.10 \\
\hline 4 & 218.64 & 5.93 & 193.09 & 7.86 & 7.51 & 0.17 & 6.01 & 0.28 \\
\hline 5 & 291.00 & 7.26 & 242.11 & 15.76 & 10.98 & 0.27 & 7.85 & 0.44 \\
\hline 6 & 384.39 & 8.00 & 331.69 & 14.85 & 15.38 & 0.33 & 12.94 & 0.44 \\
\hline 7 & 446.39 & 8.46 & 434.23 & 21.99 & 18.85 & 0.41 & 17.15 & 0.74 \\
\hline 8 & 501.20 & 7.70 & 476.31 & 16.64 & 22.36 & 0.34 & 20.75 & 0.74 \\
\hline 9 & 539.96 & 9.28 & 494.23 & 15.25 & 24.91 & 0.41 & 24.37 & 0.51 \\
\hline 10 & 577.81 & 11.55 & 475.71 & 22.48 & 28.17 & 0.48 & 26.07 & 0.78 \\
\hline 11 & 595.32 & 12.09 & 505.00 & 23.45 & 30.68 & 0.24 & 28.78 & 0.60 \\
\hline 12 & 586.42 & 10.99 & - & - & 32.78 & 0.33 & - & - \\
\hline 13 & 584.30 & 12.04 & - & - & 34.71 & 0.23 & - & - \\
\hline 14 & 578.37 & 11.27 & - & - & 35.78 & 0.34 & - & - \\
\hline 15 & 572.75 & 14.13 & - & - & 37.23 & 0.27 & - & - \\
\hline 16 & 556.67 & 25.98 & - & - & 36.77 & 0.96 & - & - \\
\hline
\end{tabular}
class includes periods of three days. SE $=$ Standard Error. 


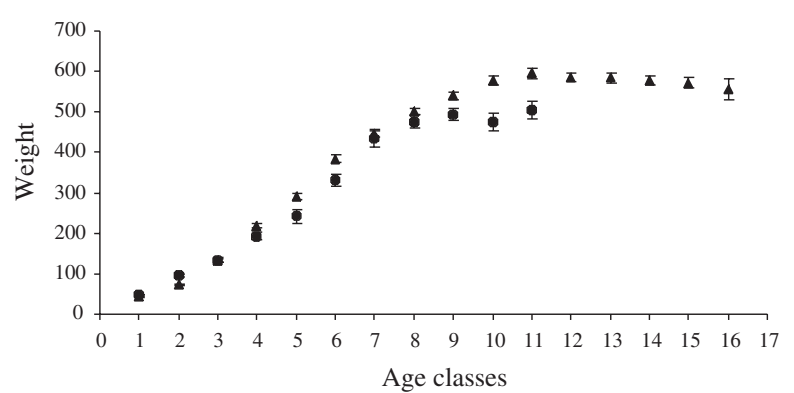

FIG. 1. - Average ( \pm SE) weight gain (g) for each age class of wild reared Audouin's gull (Larus audouinii) chicks, $\mathrm{N}=106$ (solid black dots) and captive reared chicks, $\mathrm{N}=45$ (solid black triangles). Each age class includes periods of three days.

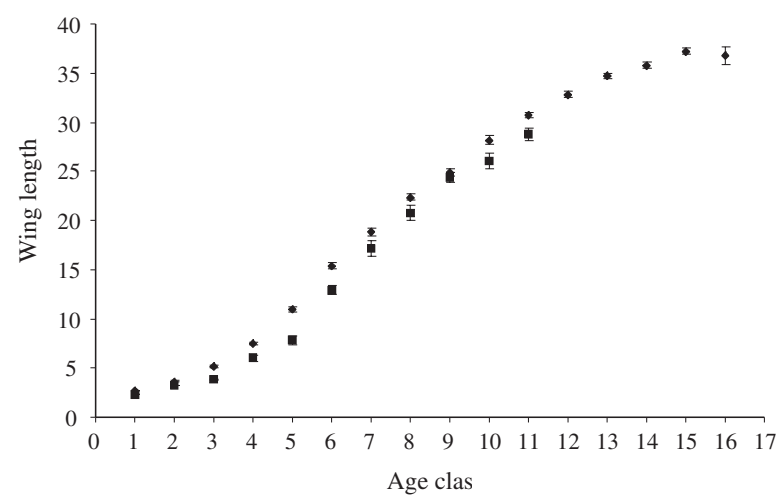

FIG. 2. - Average increase $( \pm \mathrm{SE})$ of wing length $(\mathrm{cm})$ for each age class of wild reared Audouin's gull (Larus audouinii) chicks, $\mathrm{N}=106$ (solid black dots) and captive-reared chicks, $\mathrm{N}=45$ (solid black triangles). Each age class includes periods of three days.

asymptotic (age classes 10 to 16) phases were considered separately. Mean growth rates in the linear stage (i.e. slopes), asymptotic means from both locations and mean egg volume were compared by means of t-tests (two-tailed) and Mann-Whitney Utests (Zar, 1999).

\section{RESULTS}

Average weight gain for each 3-day age class of Audouin's Gull chicks from the Ebro Delta and captivity are shown in Table 1 and Figure 1. Captivereared chicks (age class 1) hatched with a lower mean weight than wild ones $(\mathrm{U}=690.5, \mathrm{P}=$ $0.0001)$. Weight gain rates from age classes 2 to 8 were not significantly different $(\mathrm{t}=0.53, \mathrm{P}=0.609)$ but the asymptotic weight of the captive-reared chicks was significantly higher than that of wild ones $(\mathrm{t}=4.07, \mathrm{P}<0.001)$.

The average increase in wing length for each age class of Audouin's Gull chicks from the Ebro Delta and captivity is displayed in Figure 2. Captive- reared chicks hatched (age class 1) with a higher mean wing length than wild ones $(\mathrm{U}=234.5, \mathrm{P}=$ 0.0001). However, wing length growth rates from age classes 2 to 8 were not significantly different $(\mathrm{t}=$ $0.35, \mathrm{P}=0.735)$ between captive and wild-reared chicks. Since wing measurement data from the asymptotic region for wild chicks were missing, we were not able to compare them with captive-reared chicks.

The mean volume of eggs from the Columbretes Islands and the Ebro Delta are shown in Figure 3. Eggs from the Ebro Delta were significantly larger than those from the Columbretes Islands $(\mathrm{U}=$ 7768.0, $\mathrm{P}=0.0002$ ).

\section{DISCUSSION}

The fact that eggs from the Ebro Delta were larger than eggs from Columbretes suggests a better mean body condition of the Ebro Delta females. Though eggs from the Columbretes Islands were smaller and chicks hatched with a lower mean weight than chicks from the Ebro Delta, the asymptotic weight of chicks from Columbretes eggs was finally higher. This suggests that posthatch factors (i.e. amount of food delivered especially during the last phases of chick growth) have a stronger influence on the final chick mass than prehatch factors (i.e. egg size), as previously indicated by Bolton (1991). According to sex ratio theory (Oddie, 1998; Nager et al., 1999) females under food-stress conditions would favor the production of female offspring. This could explain why chicks from the Ebro Delta had a lower asymptotic weight if reproductive females from the Ebro Delta were shown to be food stressed and assuming that female chicks weigh less

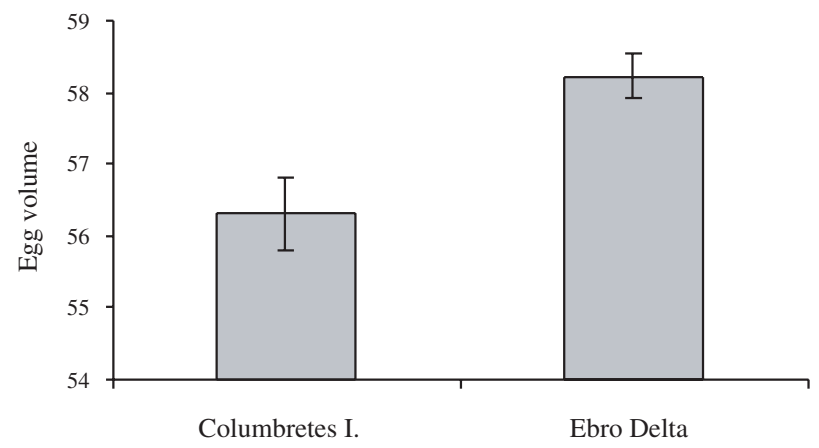

FIG. 3. - Mean ( $\pm \mathrm{SE})$ egg volume $\left(\mathrm{cm}^{3}\right)$ of Audouin's gull (Larus audouinii) eggs from the Columbretes Islands and the Ebro Delta. Volume was calculated by the equation: egg volume $\left(\mathrm{cm}^{3}\right)=$ $0.000467 \mathrm{x}$ length $(\mathrm{mm}) \mathrm{x}$ width $^{2}(\mathrm{~mm})$, after Hoyt (1979). 
on average than male chicks. However, the foodstress period in the Ebro Delta did not coincide with the pre-incubation period (i.e. when sex would be determined in the egg) but with the chick-rearing period. Hence, the differences observed cannot be explained by skewed sex ratios.

The fact that captive-reared chicks reached their fledging period with a higher mass than chicks from wild gulls but had similar growth rates during the early phase of growth suggests that wild gulls were not able to provide as much food as chicks can eat. This could be due to the conditions of reduced food availability at the Ebro Delta caused by the trawlingfishing moratorium. Alternatively, wild gulls from the Ebro Delta could be subjected to a trade-off between present and future reproduction, as predicted by life-history theory (Reznick, 1985). Fledging size seems to be determined during the beginning of the asymptotic phase, both for wing length and weight, the phase of linear growth not being very relevant. Finally, egg size did not have any influence on the wing length of hatchlings. This is probably related to the fact that wing length at hatching time is less important for survival than at fledging time (Soler and Soler, 1990).

The future demographic consequences (e.g. influence on survival, recruitment and life-time reproductive performance) of reduced food availability for chicks from the 1993 Ebro Delta cohort should be explored in further work.

\section{ACKNOWLEDGEMENTS}

We are grateful to Daniel Oro for providing data on growth of chicks from the Ebro Delta and to the C.P.E.M.N staff, mainly Juan Antonio Gómez López, for their help in this project. We also thank the Benidorm and Columbretes Islands wardens for their help during fieldwork. We thank Alejandro Martínez-Abraín for his help during office work. This study was carried out as part of the Audouin's gull Conservation Actions included in the LIFENATURE programme BA 3200/98/447 “Conservation of island SPAs in the Valencian Region". Finally, we are very grateful to Jacob Gonzalez Solís and M. Harris for their thorough review of a draft of the paper.

\section{REFERENCES}

Bolton, M. - 1991. Determinants of chicks survival in the lesser black-backed gull: relative contributions of egg size and parental quality. J. Anim. Ecol., 60: 949-960.

Bolton, M., D. Houston and P. Monaghan. - 1992. Nutritional constraints on egg formation in the lesser black-backed gull: an experimental study. J. Anim. Ecol., 61: 521-532.

Bolton, M., P. Monaghan and D. Houston. - 1993. Proximate determination of clutch size in lesser black-backed: the role of food supply in body condition. Can. J. Zool., 71: 273-279.

Coulson, J.C. and J.M. Porter. - 1985. Reproductive success of the kittiwake Rissa tridactyla: the roles of clutch size, chick growth rates and parental quality. Ibis, 127: 450-466.

Hébert, P.N. and R.M.R. Barclay. - 1988. Parental investment in herring gulls: clutch apportionment and chick survival. Condor, 90: 332-338.

Hiom, L., M. Bolton, P. Monaghan and D. Worrall. - 1991. Experimental evidence for food limitation of egg predation in gulls. Ornis Scand., 22: 94-97.

Hoyt, D.F. - 1979. Practical methods of estimating volume and fresh weight of bird eggs. Auk, 96: 73-77.

Nager, R.G., P. Monaghan, R. Griffiths, D.C. Houston and R. Dawson. - 1999. Experimental demonstration that offspring sex ratio varies with maternal condition. Ecology, 96: 570-573.

Nisbet, I.C.T. - 1978. Dependence of fledging success on egg size, parental performance and egg composition among common and roseate terms, Sterna hirundo and S. dougallii. Ibis, 120: 207-215.

Oddie, K. - 1998. Sex discrimination before birth. Trends Ecol. Evol., 13: 130-131.

Oro, D., L. Jover and X. Ruiz. - 1996a. Influence of trawling activity on the breeding ecology of a threatened seabird, Audouin's gull Larus audouinii. Mar. Ecol. Prog. Ser. 139: 19-29

Oro, D., X. Genovart, X. Ruiz, J. Jiménez and J. García-Gans. 1996b. Differences in diet, population size and reproductive performance between two colonies of Audouin's Gull Larus audouinii affected by a trawling moratorium. J. Avi. Biol., 27: 245-251.

Pons, J.M. and P. Migot. - 1995. Life-history strategy of the herring gull: changes in survival and fecundity in a population subjected to various feeding conditions. J. Anim. Ecol., 64: 592-599.

Reznick, D. - 1985. Costs of reproduction: an evaluation of the empirical evidence. Oikos, 44: 257-267.

Risch, T.S. and F. C. Rohwer. - 2000. Effects of parental quality and egg size on growth and survival of herring gull chicks. Can. J. Zool., 78: 967-973.

Soler, J and C. Soler. - 1990. Crecimiento de los pollos de Grajilla (Corvus monedula), relación entre desarrollo y comportamiento petitorio. Ardeola, 37: 37-52.

SPSS for Windows, Re. 10.0.6. - 1999. SPSS Inc, Chicago

Zar, J. H. - 1999. Biostatistical analysis. Prentice Hall, New Jersey. 